\title{
Analisis Budget Kas Dalam Meningkatkan Likuiditas dan Profitabilitas Perusahaan
}

\author{
${ }^{1}$ Lydia Resti Elaksmi \\ ${ }^{2}$ Darti Djuharni \\ STIE Malangkuçeçwara Malang \\ Jalan Terusan Candi Kalasan Blimbing Malang - 65125 \\ Email: dartidjuharni@yahoo.com
}

\begin{abstract}
The purpose of the study to find out how the cash budget implementation at metal company UD Lancar Jaya, Tulungagung in increasing liquidity and profitability. The research method used is case study research. The researcher conducts financial ratio analysis consisting of analysis of liquidity and profitability through financial statements, namely the income statement and balance sheet for 2015-2017 and prepares financial report projections in 2018. The analysis shows that the company faces the problem that is using inefficient funds Keyword: cash budget; liquidity; profitability
\end{abstract}

\begin{abstract}
Abstrak
Penelitian ini bertujuan untuk mengetahui bagaimana aplikasi budget kas pada perusahaan logam UD Lancar Jaya, Tulungagung dalam meningkatkan likuiditas dan profitabilitas. Metode penelitian yang digunakan adalah penelitian studi kasus. Peneliti melakukan analisis rasio keuangan yang terdiri atas analisis likuiditas dan profitabilitas melalui laporan keuangan 2015-2017 dan menyusun proyeksi laporan keuangan tahun 2018. Hasil analisis menunjukkan perusahaan menghadapi masalah penggunaan dana yang kurang efisien.
\end{abstract}

Kata kunci: budget kas; likuiditas; profitabilitas

\section{PENDAHULUAN}

Setiap perusahaan seharusnya menyusun budget atau anggaran sebagai alat pengendali dalam melaksanakan setiap kegiatan usahanya (Kusnadi \& Iriyadi, 2012). Ketika perusahaan menjalankan aktifitasnya, maka dibutuhkan perencanaan dan pengaturan keuangan. Menurut Basori (2017), untuk 
merencanakan dan mengatur keuangan perusahaan dibutuhkan suatu alat yang dinamakan budget kas yang fungsinya untuk memberi informasi mengenai penerimaan dan pengeluaran kas. Penyusunan budget kas itu penting, karena menunjukkan posisi kas pada akhir periode. Dengan demikian dapat diketahui posisi kas saat itu apakah mengalami surplus atau deficit. Budget kas dapat membantu manajer menghindari dari kelebihan kas yang tidak terpakai maupun kekurangan kas (Basori, 2017). Kegunaan lain dalam penyusunan budget kas adalah sebagai tolak ukur untuk mengetahui apakah perusahaan dalam keadaan likuid atau tidak (Septiyani, 2013), sehingga Dengan budget kas dapat digunakan oleh perusahaan untuk mengetahui struktur keuangan guna meningkatkan profitabilitas dan likuiditas.

Lebih lanjut Septiyani (2013) menyatakan, apabila perusahaan tidak mempunyai persediaan kas yang cukup untuk membayarkan utang pada jatuh tempo yang berarti perusahaan tidak dalam kondisi likuid, maka akan berpengaruh terhadap kepercayaan pihak luar perusahaan. Adanya kas yang cukup memungkinkan bagi perusahaan untuk beroperasi secara maksimal serta tidak mengalami kesulitan akibat krisis keuangan, akan tetapi kas berlebih menunjukkan kondisi yang kurang baik, karena hal itu berarti ada dana yang tidak produktif (Nugroho, 2012). Disisi lain menurut Hasmita (2015) likuiditas mempunyai hubungan cukup erat dengan kemampuan memperoleh laba atau biasa disebut istilah profitabilitas, karena likuiditas menunjukkan tingkat ketersediaan kas yang dibutuhkan dalam aktivitas operasional. Dengan kata lain, perusahaan dikatakan berhasil dalam kegiatan usahanya apabila secara terus menerus mampu memenuhi kewajiban finansial jangka pendeknya dan mendapatkan laba merupakan syarat mutlak dalam menjamin kelangsungan hidup suatu perusahaan.

Profitabilitas merupakan salah satu indikator kinerja yang dilakukan oleh pihak manajemen dalam mengelola laba perusahaan. Profitabilitas akan menunjukkan perbandingan pendapatan dan kemampuan perusahaaan dalam menghasilkan laba pada berbagai tingkat operasi, sehingga rasio ini akan menceminkan efektifitas dan keberhasilan manajemen secara keseluruhan (Wibowo \& Wartin, 2012). Profitabilitas dapat menunjukkan perusahaan tersebut memiliki prospek yang baik di masa akan datang (Hermuningsih, 2013). Oleh karena itu, menurut Wibowo and Wartin (2012) perusahaan harus mencari sumber dana yang berasal dari luar perusahaan untuk menjaga kelangsungan usahanya. Pemenuhan kebutuhan dana yang berasal dari luar perusahaan dapat diperoleh dari pihak kreditur seperti bank atau lembaga keuangan lainnya. Kesimpulannya profitabilitas merupakan elemen penting dalam menjamin kelangsungan perusahaan. Dengan adanya kemampuan 
124 Akuntansi Bisnis dan Manajemen (ABM), Vol. 26, No 2, Oktober 2019

memperoleh laba menggunakan semua sumber daya perusahaan maka tujuan untuk memperoleh laba yang tinggi akan tercapai.

Beberapa peneliti telah melakukan penelitian tentang analisis budget kas dalam meningkatkan likuiditas dan profitabilitas perusahaan, di antaranya Septiyani (2013) yang melakukan penelitian pada perusahaan kacang sanghai "Gangsar". Berdasarkan hasil analisis budget kas yang dilakukanya tingkat likuiditas dan profitabilitasnya berfluktuatif. Basori (2017) menunjukkan hasil analisis perencanaan budget kas dalam upaya menjaga tingkat likuiditas usaha pada keuangan Koperasi "SAE" Pujon selama periode tahun 2013-2015 menggambarkan perubahan tingkat likuiditas dan profitabilitas, walaupun dalam beberapa indikator rasio masih terjadi fluktuasi. (Riskia, Hidayat, \& Dwiatmanto, 2014)hasil analisis penggunaan budget kas untuk menjaga likuiditas dan meningkatkan rentabilitas pada tahun 2011 sampai tahun 2013 di PT Kalbe Farma Tbk mengalami keadaan likuiditas yang over liqiud. Berdasarkan penelitian-penelitian tersebut hasil analisis yang dilakukan para peneliti yang sebelumnya berbeda-beda. Oleh karena itu peneliti tertarik untuk melakukan penelitian lebih lanjut mengenai hasil dari analisis budget kas dalam meningkatkan likuiditas dan profitabilitas dengan tujuan menganalisis peranan budget kas dalam meningkatkan profitabilitas dan likuiditas perusahaan.

\section{METODE PENELITIAN}

Penelitian ini menggunakan jenis penelitian studi kasus, karena peneliti ingin mengetahui secara rinci dan menyeluruh kejadian yang ada di UD Lancar Jaya, serta menganalisis dan mengevaluasi aktivitas yang berkaitan dengan penyusunan budget kas secara mendalam.Sumber data penelitian diperoleh dari pihak yang menjalankan aktivitas perusahaan sehari-hari, antara lain: (1) dari pemilik perusahaan, berupa deskripsi perusahaan, visi-misi-dan tujuan perusahaan, pembagian tugas dan wewenang masing-masing staff di dalam organisasi. (2) dari bagian akuntansi, peneliti memperoleh data mengenai pengelolaan keuangan di dalam perusahaan; (3) dari bagian gudang peneliti memperoleh data mengenai penerimaan, penyimpanan, dan pengeluaran barang; (4) dari bagian pembelian, peneliti memperolah data mengenai pembelian bahan baku; (5) dari bagian penjualan, peneliti memperoleh data yang terkait dengan penjualan barang; dan (6) dari bagian produksi, peneliti memperoleh data mengenai proses produksi. Data dikumpulkan melalui tiga cara yaitu observasi partisipatif, wawancara, dan dokumentasi.

Pengumpulan data melalui observasi partisipatif, peneliti lakukan dengan ikut terlibat langsung dalam kegiatan perusahaan melalui magang kerja selama 
Budget Dalam Meningkatkan Likuiditas \& Profitabilitas (Lydia \& Darti ) 125

satu bulan, dan peneliti berkeliling di beberapa bagian terkait dengan topik kajian ini. Pengumpulan data melalui wawancara dilakukan kepada berbagai pihak sebagaimana telah diuraikan pada alenea sebelumnya. Selanjutnya untuk melengkapi data yang dibutuhkan peneliti mengumpulkan berbagai dokumen yang terkait dengan topik bahasan antara lain berupa laporan keuangan tahunan perusahaan, data penjualan per bulan, nota pengiriman barang jadi, dan data pengumpulan piutang usaha.

Data-data yang telah terkumpul, kemudian peneliti lakukan analisis dan evaluasi melalui tahapan berikut: pertama, deskripsi kegiatan perusahaan terkait dengan pengelolaan kas. Kedua, menghitung rasio likuditas, dengan menggunakan current ratio, quick ratio, dan cash ratio.Ketiga, menghitung dan menganalisis profitabilitas melalui; margin laba bersih, margin laba bruto, dan margin laba operasi.Keempat, membuat ramalan budget kas melalui ramalan pendapatan penjualan, ramalan beban pokok penjualan, menyusun budget penerimaan kas, menyusun budget pengeluaran kas, dan terakhir menyusun budget kas.

\section{HASIL DAN PEMBAHASAN}

Berdasarkan tahapan analisis yang telah diuraikan pada bagian sebelumnya, pembahasan hasil penelitian diuraikan sebagai berikut.

UD Lancar Jaya merupakan salah satu perusahaan yang bergerak di bidang pertanian, khususnya pembuat suku cadang alat pertanian yang berasal dari logam. Perusahaan ini juga melayani pesanan sesuai permintaan konsumen baik bentuk maupun modelnya. Perusahaan ini berdiri sejak tahun 2000, dan memasarkan barangnya melalui toko-toko peralatan pertanian dan industri besar maupun kecil di wilayah Indonesia, khususnya di Jawa Timur. Harga jual produk ditentukan perusahaan dengan menggunakan cost plus pricing method, yaitu suatu metode dimana produsen menetapkan harga jual untuk satu unit barang yang besarnya sama dengan jumlah biaya per unit ditambah de-ngan sejumlah laba yang diinginkan. Penjualan barang dilakukan secara tunai dan kredit, serta kepada pengeceer diberi potongan $7 \%$.Untuk penjualan kredit kebijaksanaan yang diberikan adalah 5/10-n/30.

Dari hasil pengamatan dan wawancara diketahui bahwa selama ini perusahaan tidak pernah menyusun budget kas. Hal ini terungkap melalui wawancara dengan pemilik perusahaan tanggal 11 Januari 2019, saat peneliti menanyakan apakah bapak selama ini membuat budget kas? Pemilik menjawab : "Tidak mbak". Hal ini dikatakannya selain pemilik tidak paham fungsi dari penyusunan budget kas, juga karena dia menganggap tidak perlu. Setelah 
126 Akuntansi Bisnis dan Manajemen (ABM), Vol. 26, No 2, Oktober 2019

peneliti menjelaskan apa fungsi dan manfaat dari penyusunan budget kas, beliau menjawab: hhmmm. iya mbak, saya selama ini tidak tahu tentang hal itu.. Soalnya kalau dipikir ini perusahaan yang tidak terlalu besar jadi saya tidak memikirkan hal tersebut..

Selanjutnya peneliti juga menanyakan bagaimana beliau mengetahui kalau perusahaan itu memperoleh laba atau menderita kerugian serta mengetahui surplus atau defisitnya kas, beliau menjawab: Dari laporan laba rugi itu mbak, kan di sana sudah ada catatan laba nya, serta ada tambahan pendapatan dari jual sisa logam itu.Data Laporan Keuangan yang berhasil peneliti peroleh adalah:

Tabel 1. Neraca tahun 2015,2016, 2017 (Dalamribuan Rupiah)

\begin{tabular}{lrrr}
\hline \multicolumn{1}{c}{ Uraian } & $\mathbf{2 0 1 5}$ & $\mathbf{2 0 1 6}$ & \multicolumn{1}{c}{$\mathbf{2 0 1 7}$} \\
\hline Aktiva & & & \\
\hline Kas dan Setara Kas & 125.000 & 158.000 & 176.000 \\
Piutang Usaha & 113.000 & 134.000 & 152.000 \\
Persd. Bahan Baku & 84.000 & 94.500 & 105.000 \\
Persd. Bahan Dlm Proses & 52.000 & 60.000 & 72.000 \\
Persd. Bahan Jadi & 40.500 & 37.000 & 40.000 \\
Bangunan & 100.000 & 283.000 & 266.900 \\
Mesin & 60.000 & 65.000 & 66.700 \\
Kendaraan & 200.000 & 160.000 & 128.000 \\
Akm. Penyusutan & -127.000 & -111.100 & -97.864 \\
Total Aktiva & $\mathbf{6 4 7 . 5 0 0}$ & $\mathbf{8 8 0 . 4 0 0}$ & $\mathbf{9 0 8 . 7 3 6}$ \\
Pasiva & & & \\
Utang Usaha & 197.000 & 260.000 & 262.000 \\
Utang Bank & 329.500 & 440.400 & 474.736 \\
Modal Pemilik & 121.000 & 180.000 & 172.000 \\
Total pasiva & $\mathbf{6 4 7 . 5 0 0}$ & $\mathbf{8 8 0 . 4 0 0}$ & $\mathbf{9 0 8 . 7 3 6}$ \\
\hline
\end{tabular}

Data berikutnya terkait dengan Laporan laba - Rugi 
Budget Dalam Meningkatkan Likuiditas \& Profitabilitas (Lydia \& Darti ) 127

Tabel 2. Laporan Laba Rugi untuk periode 2015, 2016, dan 2016

(Dalam ribuan Rupiah)

\begin{tabular}{lrrr}
\hline \multicolumn{1}{c}{ Keterangan } & \multicolumn{1}{c}{$\mathbf{2 0 1 5}$} & $\mathbf{2 0 1 6}$ & \multicolumn{1}{c}{$\mathbf{2 0 1 7}$} \\
\hline Penjualan & 440.000 & 468.000 & 490.000 \\
Beban Pokok Penjualan & -100.900 & -109.200 & -119.600 \\
Laba(Rugi) Kotor & 339.100 & 328.800 & 370.400 \\
Beban Usaha & -110.000 & -126.000 & 134.000 \\
Laba (Rugi) Usaha & $\mathbf{2 2 9 . 1 0 0}$ & $\mathbf{2 3 2 . 8 0 0}$ & $\mathbf{2 3 6 . 4 0 0}$ \\
Pendapatan (Beban) Lain-Lain & & & \\
Pendapatan Di Luar Usaha & 155.000 & 176.000 & 192.000 \\
Beban Di Luar Usaha & -13.000 & -17.800 & -23.000 \\
Laba (Rugi) Bersih Sebelum Pajak & 371.100 & 391.000 & 405.400 \\
Pajak Penghasilan & 92.700 & 97.000 & 101.250 \\
Laba (Rugi)Bersih Setelah Pajak & $\mathbf{2 7 8 . 4 0 0}$ & $\mathbf{2 9 4 . 0 0 0}$ & $\mathbf{3 0 4 . 1 5 0}$ \\
\hline
\end{tabular}

Tahapan analisis yang kedua adalah menghitung rasio likuiditas. Analisis rasio likuiditas digunakan untuk mengukur kemampuan perusahaan dalam memenuhi kewajiban keuangan jangka pendeknya yang segera harus dipenuhi. Perhitungan rasio likuiditas dilakukan dengan tiga cara yaitu;

\section{Current Rasio}

Rasio ini digunakan untuk mengukur kemampuan perusahaan membayar kewajiban jangka pendek dengan aktiva lancar. Perhitungan Current Ratio dilakukan dengan menggunakan rumus sebagai berikut.

$$
\frac{\text { Aktiva Lancar }}{\text { Kewajiban Jangka Pendek }} \times 100 \%
$$

Hasil perhitungan Current Ratio selama tiga tahun tampak pada tabel 3. 
128 Akuntansi Bisnis dan Manajemen (ABM), Vol. 26, No 2, Oktober 2019

Tabel 3. Current Ratio (dalam ribuan)

\begin{tabular}{ccccc}
\hline Tahun & $\begin{array}{c}\text { Aktiva } \\
\text { Lancar } \\
(\mathbf{a})\end{array}$ & $\begin{array}{c}\text { Kewajiban } \\
\text { Jangka Pendek } \\
(\mathbf{b})\end{array}$ & $\begin{array}{c}\text { Current Ratio } \\
(\mathbf{a b})\end{array}$ & $\begin{array}{l}\text { Kenaikan/ } \\
\text { Penurunan }\end{array}$ \\
\hline 2015 & 414.500 & 197.000 & $210 \%$ & - \\
2016 & 483.500 & 260.000 & $185 \%$ & Turun 24\% \\
2017 & 545.000 & 262.000 & $208 \%$ & Naik 22\% \\
\hline
\end{tabular}

Berdasarkan hasil perhitungan sebagaimana tampak pada tabel 3 current ratio pada tahun 2015 dan 2017 nilainya overlikuid jika dibandingkan dengan nilai standar current ratio yang berkisar $200 \%$. Hal ini dapat diartikan bahwa pada tahun tersebut perusahaan tidak memanfaatkan aktiva lancar dan mengelola modal dengan baik. Pada tahun 2016 tingkat current ratio di bawah $200 \%$ yang artinya bahwa perusahaan kurang aktif dalam membayarkan hutang jangka pendeknya, tetapi angka yang ditunjukkan masih dalam posisi yang wajar. Analisis likuiditas berikutnya dihitung berdasarkan quick ratio.

Quick Rasio digunakan untuk menunujukkan ukuran kemampuan perusahaan dalam memenuhi kewajiban-kewajiban dengan aktiva lancar yang lebih likuid tanpa memperhitungkan persediaan, jika seandaikan dipaksa untuk segera melunasi. Semakin tinggi quick ratio berarti perusahaan semakin likuid.Tetapi quick ratio yang terlalu tinggi mengindikasikan terlalu banyak uang yang menganggur atau tidak dimanfaatkan.Perhitungan quick ratio dilakukan dengan menggunakan rumus:

$\frac{\text { Aktiva Lancar-Persediaar }}{\text { Kewa jiban Jangka Pendek }} \times 100 \%$

Hasil perhitungan quick ratio selama tiga tahun tampak pada tabel 4 berikut ini.

Tabel 4.Quick Ratio tahun 2015, 2016, dan 2017 (dalam ribuan)

\begin{tabular}{ccccc}
\hline Tahun & $\begin{array}{c}\text { Aktiva lancar }- \\
\text { Persediaan } \\
(\mathbf{a})\end{array}$ & $\begin{array}{c}\text { Kewajiban Jk. } \\
\text { Pendek } \\
(\mathbf{b})\end{array}$ & $\begin{array}{c}\text { Quick Ratio } \\
(\mathbf{a} / \mathbf{b})\end{array}$ & $\begin{array}{c}\text { Kenaikan/ } \\
\text { Penurunan }\end{array}$ \\
\hline 2015 & 238.000 & 197.000 & $120 \%$ & - \\
2016 & 292.000 & 260.000 & $112 \%$ & Turun $8 \%$ \\
2017 & 270.000 & 262.000 & $103 \%$ & Turun 9\% \\
\hline
\end{tabular}

Berdasarkan hasil perhitungan quick ratio tampak bahwa pada tahun 2017, quick ratio perusahaan turun $9 \%$. Tetapi penurunan ini masih 
Budget Dalam Meningkatkan Likuiditas \& Profitabilitas (Lydia \& Darti ) 129

menunjukkan kondisi yang baik, karena masih di atas $100 \%$. Kondisi current ratio perusahaan berdasarkan tabel 4 menunjukkan perusahaan mampu memenuhi kewajiban jangka pendeknya. Selanjutnya analisis likuiditas dinilai berdasarkan Cash Ratio.

Cash Ratio menunjukkan kemampuan kas yang dimiliki oleh perusahaan dalam memenuhi kewajiban jangka pendek perusahaan. Perhitungan cash ratio menggunakan rumusan sebagai berikut.

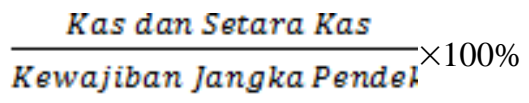

Hasil perhitungan cash ratio selama tiga tahun disajikan pada tabel 5 berikut ini.

Tabel 5. Cash Ratio (dalam ribuan)

\begin{tabular}{ccccc}
\hline Thn & $\begin{array}{c}\text { Kas dan Setara } \\
\text { Kas } \\
(\mathbf{a})\end{array}$ & $\begin{array}{c}\text { Kewajiban } \\
\text { Jangka Pendek } \\
(\mathbf{b})\end{array}$ & $\begin{array}{c}\text { Rasio Kas } \\
(\boldsymbol{\%}) \\
(\mathbf{a} / \mathbf{b})\end{array}$ & $\begin{array}{c}\text { Kenaikan/ } \\
\text { Penurunan }\end{array}$ \\
\hline 2015 & 125.000 & 197.000 & $63 \%$ & - \\
2016 & 158.000 & 260.000 & $60 \%$ & Turun 2\% \\
2017 & 176.000 & 262.000 & $67 \%$ & Naik 6\% \\
\hline
\end{tabular}

Rasio kas pada periode 2015 ke 2016 mengalami penurunan tingkat prosentase. Hasil tersebut menunjukkan bahwa kemampuan perusahaan untuk melunasi kewajiban jangka pendeknya dengan kas yang dimiliki mulai menunjukkan tingkat prosentase menurun. Terjadinya penurunan rasio kas tersebut dikarenakan adanya penurunan kas dan setara kas yang dimiliki oleh perusahaan. Rasio kas ini cukup tinggi karena menunjukkan saldo kas yang relatif tinggi sepanjang tahun. Standar rasio kas 0,2 kali atau 20\% dianggap sudah dapat diterima. Rasio kas yang terlalu tinggi menunjukkan penggunaan aset yang tidak maksimal bagi perusahaan karena menyimpan uang tunai terlalu banyak.

Berdasarkan hasil analisis rasio likuiditas, dapat disimpulkan bahwa perusahaan dalam keadaan seimbang untuk kemampuannya memenuhi kewajiban jangka pendek, baik ditinjau dari tingkat prosentase Current Ratio, Quick Ratio, maupun cash ratio. Dari analisi tersebut dapat dikatakan bahwa 
perusahaan mampu memenuhi kewajiban-kewajiban jangka pendeknya dari tahun ke tahun karena masing-masing rasio masih berada di standar yang aman yaitu 100\% untuk Quick Ratio, 20\% untuk cash Ratio, dan $200 \%$ untuk Current Ratio. Tahapan analisis yang ketiga adalah menghitung rasio profitabilitas.

Analisis rasio profitabilitas perusahaan digunakan untuk mengukur kemampuan perusahaan dalam menghasilkan laba. Hasil analisis rasio profitabilitas perusahaan selama tiga tahun terakhir dihitung melalui margin laba bersih dan margin laba bruto. Margin Laba Bersih digunakan untuk menunjukan bahwa setiap rupiah penjualan menghasilkan laba setelah pajak (Samryn, 2012) . Perhitungan ini digunakan untuk mengukur seberapa efisien manajemen mengelola perusahaannya dan juga memperkirakan profitabilitas masa depan berdasarkan peramalan penjualan. Perhitungan margin laba bersih selama tiga tahun dilakukan dengan menggunakan rumus berikut.

\section{Laba Bersih Setelah Pajak}

\section{Penjualan Bersih $\times 100 \%$}

Hasil perhitungan margin laba bersih pada tahun 2015. 2016, dan 2017 ditunjukkan pada tabel 6 berikut.

Tabel 6. Margin Laba Bersih (dalam ribuan)

\begin{tabular}{ccccc}
\hline Tahun & $\begin{array}{c}\text { Laba } \\
\text { Bersih } \\
\text { Stlh Pjk } \\
\text { (a) }\end{array}$ & $\begin{array}{c}\text { Penjualan } \\
\text { Bersih } \\
(\mathbf{b})\end{array}$ & $\begin{array}{c}\text { Margin } \\
\text { Laba } \\
\text { Bersih } \\
\text { (a/b) }\end{array}$ & Kenaikkan/Penurunan \\
\hline 2015 & 278.000 & 440.000 & $63 \%$ & - \\
2016 & 294.000 & 468.000 & $62,8 \%$ & Turun $0,4 \%$ \\
2017 & 304.150 & 490.000 & $62,07 \%$ & Turun $0,75 \%$ \\
\hline
\end{tabular}

Berdasarkan tabel 6, tampak bahwa perusahaan mengalami penurunan laba bersih $0.75 \%$. Hal ini dapat diartikan bahwa jumlah penjualan yang dihasilkan banyak digunakan untuk menutup biaya-biaya yang dikeluarkan, dan pada tahun 2016 dan 2017 peningkatan jumlah biaya yang dikeluarkan lebih besar dibandingkan omzet penjualan yang diterima. Analisis profitabilitas berikutnya dilakukan dengan menghitung margin laba bruto. Margin laba bruto digunakan untuk membandingkan kondisi perusahaan saat ini dengan kinerja masa lalu. Rumus yang digunakan untuk menghitung margin laba bruto adalah: 
Budget Dalam Meningkatkan Likuiditas \& Profitabilitas (Lydia \& Darti ) 131

$$
\frac{\text { Laba Kotor }}{\text { Penjualan Bersih }} \times 100 \%
$$

Hasil perhitungan margin laba bruto selama tiga tahun disajikan pada tabel 7 berikut ini.

Tabel 7. Margin Laba Bruto Tahun 2015, 2016, dan 2017 (dalam ribuan)

\begin{tabular}{ccccc}
\hline Tahun & $\begin{array}{c}\text { Laba Kotor } \\
(\mathbf{a})\end{array}$ & $\begin{array}{c}\text { Penjualan } \\
\text { Bersih } \\
(\mathbf{b})\end{array}$ & $\begin{array}{c}\text { Margin } \\
\text { Laba Bruto } \\
(\mathbf{a} / \mathbf{b})\end{array}$ & $\begin{array}{c}\text { Kenaikan } \\
\text { /Penurunan }\end{array}$ \\
\hline 2015 & 339.100 & 440.000 & $77 \%$ & - \\
2016 & 358.800 & 468.000 & $76 \%$ & Turun $0,39 \%$ \\
2017 & 370.000 & 490.000 & $75 \%$ & Turun $1,16 \%$ \\
\hline
\end{tabular}

Rasio yang diperoleh digunakan untuk mengukur tingkat efisiensi kegiatan produksi dan hubungan antara laba kotor dengan volume penjualan. Semakin besar Margin Laba Bruto maka semakin baik keadaan operasi perusahaan. Margin laba bruto pada periode tahun 2015 sampai 2017 mengalami penurunan prosentase sebesar $1,16 \%$, karena perbandingan pertambahan laba kotor lebih kecil daripada perbandingan penjulannya. Hal ini menunjukkan perusahaan memiliki manajemen yang kurang bagus untuk menekan beban pokok penjualan supaya tidak terjadinya kanaikkan terlalu tinggi. Berikutnya dilakukan perhitungan margin laba operasi, dengan rumusan berikut.

$$
\frac{\text { Laba Operasi }}{\text { Penjualan Bersih }} \times 100 \%
$$

Hasil perhitungan margin laba operasi selama tiga tahun ditunjukkan pada tabel 8 berikut.

Tabel 8. Margin Laba Operasi (dalam ribuan)

\begin{tabular}{ccccc}
\hline Tahun & $\begin{array}{c}\text { Laba } \\
\text { Operasi } \\
\text { (a) }\end{array}$ & $\begin{array}{c}\text { Penjualan } \\
\text { (b) }\end{array}$ & $\begin{array}{c}\text { Margin } \\
\text { Laba } \\
\text { Operasi } \\
\text { (a/b) }\end{array}$ & Kanaikkan/Penurunan \\
\hline 2015 & 229.000 & 440.000 & $52 \%$ & - \\
2016 & 232.800 & 468.000 & $49 \%$ & Turun 2\% \\
2017 & 236.400 & 490.000 & $48 \%$ & Turun 1\% \\
\hline
\end{tabular}


132 Akuntansi Bisnis dan Manajemen (ABM), Vol. 26, No 2, Oktober 2019

Rasio ini digunakan untuk mengetahui berapa banyak uang yang didapatkan oleh perusahaan di setiap penjualan. Selain itu rasio ini menunjukkan kemampuan manajemen perusahaan dalam mengendalikan biaya operasional dan biaya produksi. Semakin tinggi angka dalam rasio ini maka semakin baik operasional perusahaan karena tidak memerlukan penjualan yang terlalu besar dalam memperoleh laba bersih. Tingkat rasio Margin Laba Operasi perusahaan pada periode tahun 2015 sampai 2017 mengalami penurunan prosentase sebesar $1,5 \%$, karena beban usaha mengalami peningkatan yang kecil.

Secara keseluruhan hasil perhitungan rasio profitabilitas pada UD Lancar Jaya Ngunut-Tulungagung dapat disajikan pada tabel 9 berikut ini.

Tabel 9. UD Lancar Jaya Ngunut-Tulungagung Hasil Rasio Profitabilitas Tahun 2015-2017

\begin{tabular}{lccc}
\hline \multicolumn{1}{c}{ Alat Analisis } & $\mathbf{3 0 1 5}$ & Tahun \\
& 2016 & $\mathbf{2 0 1 7}$ \\
\hline Margin Laba Bersih & $63,27 \%$ & $62,82 \%$ & $62,07 \%$ \\
Margin Laba Bruto & $77,06 \%$ & $76,67 \%$ & $75,51 \%$ \\
Margin Laba Operasi & $52,06 \%$ & $49,74 \%$ & $48,24 \%$ \\
\hline
\end{tabular}

Indikator rasio profitabilitas pada periode tahun 2015 sampai 2017 mengalami penurunan untuk setiap indikatornya. Efektivitas dan efisiensi manajemen bisa dilihat dari laba yang dihasilkan terhadap penjualan. Semakin tinggi nilai rasio maka kondisi per-usahaan semakin baik berdasarkan rasio profitabilitas. Nilai yang tinggi melambangkan tingkat laba dan efisiensi perusahaan tinggi yang bisa dilihat dari tingkat pendapatan dan arus kas.

Tahapan selanjutnya adalah melakukan perhitungan dengan metode least square yang digunakan untuk meramalkan penjualan dan beban pokok penjualan.

$$
Y=\frac{\Sigma y}{n}+\frac{\Sigma x y}{\Sigma x^{2}} \times x
$$

Proyeksi Penjualan UD Lancar Jaya Ngunut-Tulungagung untuk tahun 2018 terdiri atas penjualan tunai dan penjualan kredit. Pada tahun 2018 penjualan kredit diestimasikan 30\%, karena selama tahun 2015 sampai 2017 rata-rata penjualan kredit adalah $30 \%$ dari total penjualan setiap tahun. Hasil perhitungan untuk ramalah penjualan 2018 tampak pada tabel 10 . 
Budget Dalam Meningkatkan Likuiditas \& Profitabilitas (Lydia \& Darti ) 133

Tabel 10. Proyeksi Penjualan Tahun 2018 (dalam ribuan)

\begin{tabular}{rcccc}
\hline \multicolumn{1}{c}{ Tahun } & $\begin{array}{c}\text { Pendapatan } \\
\text { Penjualan (Y) }\end{array}$ & $\mathbf{X}$ & $\boldsymbol{X}^{2}$ & $\mathbf{X Y}$ \\
\hline 2015 & 440.000 & -1 & 1 & -440.000 \\
2016 & 468.000 & 0 & 0 & 0 \\
2017 & 490.000 & 1 & 1 & 490.000 \\
Jumlah & 1.398 .000 & 0 & 2 & 50.000 \\
\hline
\end{tabular}

Selanjutnya dihitung ramalan beban pokok penjualan, yang hasilnya sebagai berikut.

ribuan)

Tabel 11. Ramalan Beban Pokok Penjualan Tahun 2018 (dalam

\begin{tabular}{ccccc}
\hline Tahun & $\begin{array}{c}\text { Beban Pokok } \\
\text { Penjualan (Y) }\end{array}$ & X & $X^{2}$ & XY \\
\hline 2015 & 100.900 & -1 & 1 & -100.900 \\
2016 & 109.200 & 0 & 0 & 0 \\
2017 & 119.600 & 1 & 1 & 119.600 \\
Jumlah & 329.700 & 0 & 2 & 18.700 \\
\hline
\end{tabular}

$$
\begin{aligned}
& Y=\frac{329.700 .000}{3}+\frac{18.700 .000}{2} \times 2 \\
& Y=109.900 .000+9.350 .00 \mathrm{C} \\
& Y=119.250 .00 \mathrm{C}
\end{aligned}
$$

Jadi, total beban pokok penjualan pada tahun 2018 diproyeksikan sebesar Rp.119.250.000,-

Tahapan selanjutnya menyusun budget kas tahun 2018 dengan langkahlangkah: (1) Menyusun Budget Pendapatan Penjualan; (2) Menyusun Skedul Penerimaan Piutang; (3) Menyusun Budget Penerimaan Kas. Hasil penghitungan budget Pendapatan penjualan tampak pada tabel 12 berikut ini. 
134 Akuntansi Bisnis dan Manajemen (ABM), Vol. 26, No 2, Oktober 2019

Tabel 12. Budget Pendapatan Penjualan Tahun 2018 (dalam rupiah)

\begin{tabular}{cccc} 
Bulan & $\begin{array}{c}\text { Total } \\
\text { Penjualan }\end{array}$ & $\begin{array}{c}\text { Penjualan } \\
\text { Tunai } \\
\mathbf{( 7 0 \% )}\end{array}$ & $\begin{array}{c}\text { Penjualan } \\
\text { Kredit } \\
\mathbf{( 3 0 \% )}\end{array}$ \\
\hline Januari & 40.883 & 28.639 & 12.274 \\
Februari & 39.680 & 25.576 & 10.961 \\
Maret & 38.578 & 25.567 & 10.957 \\
April & 40.282 & 27.587 & 11.823 \\
Mei & 42.887 & 28.679 & 12.291 \\
Juni & 42.586 & 32.904 & 14.101 \\
Juli & 41.885 & 29.024 & 12.439 \\
Agustus & 40.582 & 30.461 & 13.055 \\
September & 40.682 & 26.840 & 11.503 \\
Oktober & 41.985 & 28.593 & 12.254 \\
November & 40.783 & 31.660 & 13.568 \\
Desember & 40.181 & 28.162 & 12.069 \\
Total & 491.000 & 343.700 & 147.300 \\
\hline
\end{tabular}

Setelah menyusun budget pendapatan penjualan, selanjutnya disusun skedul penerimaan piutang, yang didasarkan pada pengumpulan piutang tahuntahun sebelum-nya, yaitu: (a) Diestimasikan pada akhir periode 2017 terdapat saldo piutang usaha sebesar Rp. 12.030 .000 yang akan diterima pada bulan Januari dan Februari tahun 2018 (b) 50\% dari penjualan kredit dibayar satu bulan kemudian, tanpa potongan atau bunga dan (c) $50 \%$ dari penjualan kredit dibayar dua bulan kemudian, disertai dengan bunga sebesar 5\% dari jumlah yang seharusnya dibayar. Dari kebijakan tersebut maka dapat disusun budget pengumpulan piutang unuk tahun 2018.

Selanjutnya disusun budget penerimaan kas, dengan langkah-langkah berikut. Rekapitu-lasi sumber penerimaan kas tahun 2018 berasal dari: (a) Pendapatan penjualan tahun 2018 yang diproyeksikan sebesar Rp.487.518.000,terdiri atas penjualan tunai sebesar Rp.343.700.000,- dan penjualan kredit sebesar Rp.143.818.000,- (b) Proyeksi Pendapatan Lain-lain perusahaan UD Lancar Jaya Ngunut-Tulungagung terdiri dari penjualan bahan sisa logam. Untuk tahun 2018 diperkirakan sama seperti tahun 2017 dikarenakan bunga bank tidak banyak berubah dan (c) pendapatan lainnya diestimasikan tetap sebesar Rp.192.000.000,- Sedangkan total penerimaan kas tahun 2018 adalah Rp.679.518.000,- . 
Budget Dalam Meningkatkan Likuiditas \& Profitabilitas (Lydia \& Darti ) 135

Tabel 13. Budget Penerimaan Kas Tahun 2018 (dalam ribuan)

\begin{tabular}{cccc}
\hline Keterangan & $\begin{array}{c}\text { Pendapatan } \\
\text { Penjualan } \\
\text { Tunai }\end{array}$ & $\begin{array}{c}\text { Pendapatan } \\
\text { Lain-lain }\end{array}$ & $\begin{array}{c}\text { Pelunasan } \\
\text { Piutang }\end{array}$ \\
\hline Januari & 28.639 & 16.000 & 6.015 \\
Februari & 25.576 & 16.000 & 12.452 \\
Maret & 25.567 & 16.000 & 11.924 \\
April & 27.587 & 16.000 & 11.233 \\
Mei & 28.679 & 16.000 & 11.664 \\
Juni & 32.904 & 16.000 & 12.353 \\
Juli & 29.024 & 16.000 & 13.503 \\
Agustus & 30.461 & 16.000 & 13.623 \\
September & 26.840 & 16.000 & 13.058 \\
Oktober & 28.593 & 16.000 & 12.605 \\
November & 31.660 & 16.000 & 12.166 \\
Desember & 28.162 & 16.000 & 13.217 \\
Total & 343.700 & 192.000 & 143.818 \\
\hline
\end{tabular}

Selanjutnya disusun budget pengeluaran kas, yang perhitungannya dilakukan dengan melihat semua pengeluaran setiap bulan, melalui langkahlangkah berikut: (a) Asumsikan jumlah produk yang akan diproduksi perusahaan menggunakan pola bergelombang sesuai dengan gelombang penjualannya. Yaitu, perkembangan jumlah satuan (unit) yang akan diproduksi tidak selalu sama dari waktu ke waktu yang akan datang, melainkan berfluktuatif sesuai fluktuasi penjualannya. Jadi,untuk persediaan akhir barang tahun 2012 nantinya akan dipertahankan di tahun 2018. (b) Beban usaha yang dikeluarkan diperkirakan sebesar Rp.134.000.000,- Asumsi yang digunakan yaitu peningkatan beban usaha dalam pembelian bahan baku juga meningkat per tahunnya sebanding dengan peningkatan penjualan, atas dasar pertimbangan tersebut maka dapat diproyeksikan peningkatan beban usaha pada tahun 2018 . (c) Direncanakan perusahaan akan melunasi kewajiban jangka pendeknya berupa utang usaha sebesar Rp.98.400.000,- (d) Direncanakan perusahaan akan melunasi kewajiban jangka panjangnya berupa utang bank sebesar Rp.150.000.000,- (e) Pembebanan pajak penghasilan 25\% tahun 2018 sebesar Rp.169.879.560,- (f) Beban di luar usaha diestimasikan sebesar Rp.2.900.000,. Digunakan apabila perusahaan memerlukan dana untuk kerusakan mesin atau perawatan untuk mesin. (g) Pengambilan prive setiap bulan oleh pemilik diestimasikan Rp.188.400.000,- karena pengambilan prive oleh perusahaan rutin tiga tahun berturut-turut selalu dilakukan. 
136 Akuntansi Bisnis dan Manajemen (ABM), Vol. 26, No 2, Oktober 2019

Selanjutnya peneliti menyajikan informasi tentang penyusunan budget kas, yang estimasi tahun 2018 dibuat melalui penghitungan berikut: (a) Saldo awal diperoleh dari kas tahun 2017 (b) Pendapatan penjualan tunai dari budget penerimaan kas (c) Pendapatan lain-lain diperoleh dari budget penerimaan kas (d) Penerimaan pelunasan piutang diambil dari skedul pengumpulan piutang (e) Beban usaha diambil dari budget pengeluaran kas (f) Pelunasan utang usaha diambil dari budget pengeluaran kas (g) Utang bank diambil dari budget pengeluaran kas (h) Beban pajak diambil dari budget pengeluaran kas dan (i) Beban diluar usaha diambil dari budget pengeluaran kas.

Setelah mengestimasikan penerimaan dan pengeluaran kas dari perusahaan maka dapat disusun budget kas untuk tahun 2018. Tahapan berikutnya adalah menyusun proyeksi laporan keuangan yang meliputi neraca dan rugi laba untuk tahun 2018. Untuk membuat proyeksi laba rugi 31 Desember 2018, diperlukan hasil perhitungan: (a) Ramalan penjualan tahun 2018 dengan analisa Least Square (b) Anggaran biaya-biaya baik langsung ataupun tidak langsung (c) Beban pokok penjualan diperkirakan sebesar Rp.119.250.000,- (d) Beban pokok penjualan dihitung dari ramalan beban pokok penjualan dengan menggunakan metode least square. Dengan demikian proyeksi laba rugi 2018 tampak pada tabel 14 berikut ini.

Tabel 14. Proyeksi Laporan Laba Rugi Tahun 2018 (dalam ribuan)

\begin{tabular}{lc}
\hline Penjualan & 487.518 \\
BPP & $(119.250)$ \\
Laba(Rugi) Kotor & 368.328 \\
Beban Usaha & $(134.000)$ \\
Laba(Rugi) Usaha & 234.328 \\
Pendapatan(Beban) Lain-lain & 189.100 \\
Laba(rugi) Sebelum Pajak & 423.428 \\
Pajak Penghasilan & $(169.879)$ \\
Laba(Rugi) Bersih Setelah Pajak & 253.548
\end{tabular}

Selanjutnya dibuat proyeksi neraca. Proyeksi untuk akhir tahun 2018 dilakukan dengan memperhatikan: (a) Neraca tahun 2017 (b) Budget Kas tahun 2018 dan (c) Proyeksi Laporan Laba Rugi tahun 2018. Jika saldo kas terlalu kecil maka kebijakan yang diambil dengan memperbaiki kebijakan piutang yang telah ditetapkan. Jika saldo kas terlalu besar maka kas yang ada dapat diinvestasikan. Dengan demikian maka proyeksi Neraca 31 Desember 2018 dapat disusun dalam tabel 15 berikut. 
Budget Dalam Meningkatkan Likuiditas \& Profitabilitas (Lydia \& Darti ) 137

Tabel 15. Proyeksi Neraca Tahun 2018 (dalam ribuan)

\begin{tabular}{lr|ll}
\hline \multicolumn{1}{c}{ AKTIVA } & \multicolumn{2}{c}{ PASSIVA } \\
\hline Aktiva Lancar : & 111,938 & Utang Usaha & 163,600 \\
Kas dan Setara Kas & 143,818 & & \\
Piutang Usaha & 105,000 & Utang Bank & 324,736 \\
Persediaan Bahan & 72,000 & Modal Pemilik & 360,400 \\
Baku & 40,000 & & \\
Persediaan Bahan & 472,756 & & \\
Dalam Proses & & & \\
Persediaan Bahan & & & \\
Jadi & & & \\
Total Aktiva Lancar & 266,900 & & \\
Aktiva Tetap : & 66,700 & & \\
Bangunan & 128,000 & & \\
Mesin & $-85,620$ & & \\
Kendaraan & 375,980 & & \\
Akm. Penyusutan & & & \\
Total Aktiva Tetap & $\mathbf{8 4 8 , 7 3 6}$ & Total Passiva \\
Total Aktiva & &
\end{tabular}

Selanjutnya dianalisis posisi kas yang tampak pada tabel 16 berikut.

Tabel 16. Jumlah Saldo Kas dan Prosentase Tahun 2018 (dalam ribuan rupiah)

\begin{tabular}{cccc}
\hline Tahun & Aktiva Lancar & Jumlah Saldo Kas & Prosentase \\
\hline 2017 & 545.000 & 176.000 & $3,09 \%$ \\
2018 & 472.756 & 111.938 & $4,22 \%$ \\
\hline
\end{tabular}

Dari hasil perhitungan tersebut dapat diketahui bahwa jumlah saldo kas perusahaan mengalami kenaikan, akan tetapi tetap tidak memenuhi standar optimum persediaan kas tidak kurang dari 5\%-10\% dari jumlah aktiva lancar. Tahapan yang terakhir yaitu menghitung rasio keuangan berdasarkan proyeksi laporan keuangan dan membandingkannya dengan tahun-tahun sebelumnya untuk mengetahui perubahan kondisi keuangan yang terjadi. Hasil perhitungan rasio keuangan tahun 2018 diprediksikan seperti yang tampak pada tabel 17. 
138 Akuntansi Bisnis dan Manajemen (ABM), Vol. 26, No 2, Oktober 2019

Tabel 17. Prediksi Analisis Rasio Keuangan Tahun 2018

\begin{tabular}{lcccc}
\hline \multicolumn{1}{c}{ Keterangan } & $\mathbf{2 0 1 5}$ & $\mathbf{2 0 1 6}$ & $\mathbf{2 0 1 7}$ & $\begin{array}{c}\text { Ramalan } \\
\mathbf{2 0 1 8}\end{array}$ \\
\hline Likuiditas : & & & & \\
Current Ratio & $210 \%$ & $185 \%$ & $290 \%$ & $290 \%$ \\
Quick Ratio & $120 \%$ & $112 \%$ & $156 \%$ & $156 \%$ \\
$\begin{array}{l}\text { Rasio Kas } \\
\text { Profitabilitas: }\end{array}$ & $63 \%$ & $60 \%$ & $67 \%$ & $68 \%$ \\
Margin Laba Bersih & $63 \%$ & $62 \%$ & $62 \%$ & $52 \%$ \\
$\begin{array}{l}\text { Margin Laba Bruto } \\
\text { Margin Laba }\end{array}$ & $77 \%$ & $76 \%$ & $75 \%$ & $75 \%$ \\
Operasi & $52 \%$ & $49 \%$ & $48 \%$ & $48 \%$ \\
\hline
\end{tabular}

Berdasarkan perhitungan hasil analisis rasio untuk tahun 2018 tingkat likuiditas mengalami peningkatan dibandingkan dengan tahun sebelumnya. Peningkatan ini terjadi secara signifikan, karena adanya penetapan saldo kas serta pengalokasian dana kas untuk kepentingan pembayaran utang usaha, utang bank, pengambilan prive, serta perawatan untuk mesin perusahaan. Sebaliknya berdasarkan perhitungan di atas, tingkat profitabilitas perusahaan nilainya kurang baik, karena margin laba bersih mengalami penurunan yang disebabkan adanya peningkatan biaya-biaya produksi. Kenaikan margin laba bruto yang hanya $0,04 \%$, menunjukkan bahwa perusahaan belum mampu meningkatkan laba kotor dengan volume penjualan yang ada. Margin laba operasi mengalami penurunan sebesar $0,18 \%$, dikarenakan beban usaha mengalami peningkatan dari tahun sebelumnya.

Berdasarkan hasil semua analisis yang telah dilakukan, dapat disimpulkan bahwa penyusunan budget kas itu penting untuk mengendalikan dan meningkatkan kemampuan perusahaan dalam membayar kewajiban jangka pendek serta dalam upaya meningkatkan laba per-usahaan

\section{KESIMPULAN}

Berdasarkan hasil dan pembahasan pada bab sebelumnya, maka dapat dipaparkan beberapa kesimpulan sehingga diharapkan mampu memberikan saran kepada perusahaan UD Lancar Jaya dalam menentukan berbagai kebijakan manajemen dalam hal peranan budget kas dalam meningkatkan likuiditas dan profitabilitas perusahaan. Beberapa kesimpulan yang diperoleh adalah sebagai berikut: (a) Perusahaan belum menerapkan budget kas dalam pelaksanaan kegiatannya, karena selama ini pemimpin perusahaan belum 
Budget Dalam Meningkatkan Likuiditas \& Profitabilitas (Lydia \& Darti ) 139

paham tentang pentingnya penyusunan budget kas. (b) Hasil analisis rasio keuangan UD Lancar Jaya Ngunut-Tulungagung selama periode 2015 sampai 2017 menunjukkan pertumbuhan, baik tingkat likuiditas maupun profitabilitas, walaupun dalam beberapa indikator rasio masih terjadi fluktuasi. Penurunan rasio likuiditas terjadi pada tahun 2016 dan 2017 karena perbandingan kenaikkan aktiva lancar lebih kecil daripada kenaikkan utang lancar dari aktiva lancar. Penurunan rasio profitabilitas pada periode tahun 2016 dan 2017 juga mengalami penurunan karena perbandingan laba lebih besar daripada penjualannya. (c) Hasil penyusunan budget kas pada tahun 2018 menunjukkan hasil kurang baik. Hal ini dapat terlihat dari saldo kas optimal sebesar 4,22\%. Rasio likuiditas menunjukkan peningkatan current ratio sebesar 290,03\%, quick ratio sebesar $156,67 \%$, rasio kas sebesar $68,67 \%$. Penurunan profitabilitas dari tahun sebelumnya dimana margin laba bersih 52,08\%, margin laba bruto $75,55 \%$, dan margin laba operasi 48,06\%. (d) Besarnya kenaikan beban usaha yang ditanggung pada periode tahun 2015 sampai 2017 cenderung tinggi. Hal ini mengindikasikan bahwa manajemen tidak mampu mengendalikan beban usaha secara efisien sehingga berpengaruh kepada laba operasional bersih yang semakin menurun setiap tahunnya. (e) Selisih pendapatan (beban) lain-lain yang diperoleh perusahaan pada periode 2015 sampai 2017 terjadi sangat signifikan. Manajemen perusahaan kurang efektif dalam mengelola pendapatan (beban) lain-lain karena terjadi fluktuatif yang sangat jauh setiap tahunnya. Hal ini mengakibatkan laba bersih yang diterima tidak maksimal. (f) Profit yang diperoleh perusahaan masih terlalu rendah. Banyak faktor yang mengakibatkan laba rendah seperti, beban usaha yang cenderung meningkat lebih besar dari pendapatan dan beban lain-lain serta pengambilan prive sehingga mengurangi laba bersih yang akan diperoleh perusahaan.

\section{DAFTAR PUSTAKA}

Basori, R. K. (2017). Analisis Perencanaan Budget Kas Dalam Upaya Menjaga Tingkat Likuiditas Usaha (Studi Kasus pada Koperasi "SAE" Pujon Periode 2013-2017). Administrasi Bisnis, 45.

Hasmita. (2015). Analisis Pengaruh Tingkat Likuiditas Terhadap Profitabilitas Pada PT INDOSAT TBK. Manajemen.

Hermuningsih, S. (2013). Pengaruh Profitabilitas, Growth Opportunity, Struktur Modal Terhadap Nilai Perusahaan Publik Di Indonesia. Buletin Ekonomi Moneter Dan Perbankan

Kusnadi, A., \& Iriyadi. (2012). Analisis Peranan Anggaran Kas Sebagai Alat Bantu Manajemen Dalam Menunjang Efektivitas Pengendalian Kas. Ekonomi. 
140 Akuntansi Bisnis dan Manajemen (ABM), Vol. 26, No 2, Oktober 2019

Nugroho, S. B. (2012). Analisis Pengaruh Efisiensi Modal Kerja, Likuiditas dan Solvabilitas Terhadap Profitabilitas. Ilmu Administrasi Bisnis, 1.

Riskia, A., Hidayat, R., \& Dwiatmanto. (2014). Penggunaan Budget Kas Untuk Menjaga Likuiditas Dan Meningkatkan Rentabilitas. Jurnal Administrasi Bisnis (JAB), vol. 5(no. 2), 1-17.

Samryn, L. M. (2012). Akuntansi Manajemen : Informasi Biaya Untuk Mengendalikan Aktivitas Operasi Dan Investasi. Jakarta: Prenadamedia Group.

.Septiyani, E. (2013). Analisis Budget Kas Dalam Meningkatkan Likuiditas dan Profitabilitas Perusahaan (Studi Kasus pada Perusahaan Kacang Sanghai "Gangsar" Tulungagung). Administrasi Bisnis, 5, 2.

Wibowo, A., \& Wartin, S. (2012). Efisiensi Modal Kerja, Likuiditas Dan Leverage Terhadap Profitabilitas Pada Perusahaan Manufaktur di BEI. Dinamika Manajemen, 3, 49-58. 